\title{
ANALISIS PENGARUH PEMBERIAN INSENTIF TERHADAP KINERJA KARYAWAN PADA PT. ISTANA DELI KENCANA MEDAN
}

\author{
Betniar Purba \\ Universitas Katolik Santo Thomas Medan Jl. Setia Budi No. 479F, 20132, Indonesia \\ e-mail: betniarpurba20@gmail.com
}

\begin{abstract}
The purpose of this study was to find out and analyze the effect of giving incentives on employee performance at PT. Deli Kencana Palace Medan, for the development of science, especially in the field of human resource management, as a reference in conducting further research for the development of science, especially in the field of human resource management, as a reference in conducting further research. The research population is incentives and the number of vehicles serviced by employees of PT. Deli Kencana Palace Medan from 1983-2016. The research sample was taken in 2016. The data collection techniques used were documentation techniques. The data analysis technique used is simple linear regression. From the results of the research and discussion obtained a simple linear regression equation is $Y=515,462+0,033 X$. That is, giving incentives has a positive effect on employee performance at PT. Medan Deli Kencana Palace. This can be seen from the regression coefficient which is positive. The value of the correlation coefficient $(R)$ is 0.693, meaning that giving incentives has a fairly strong and positive relationship to the performance of employees at PT. Medan Deli Kencana Palace. The determinant coefficient (R2) is 0.481. That is, employee performance can be explained by giving incentives of $48.1 \%$ while $51.9 \%$ is explained by other factors. Judging from the $z$ test, the $z$ calculated value is 7.574 with a significance level of $0.000<)=0.05$, so HO is rejected and H1 is accepted. That is, giving incentives has a significant effect on employee performance at PT. Medan Deli Kencana Palace. PT. Deli Kencana Palace Medan has not been optimal, this can be seen from the large percentage of mechanics who are unable to achieve the set performance standards, because the amount of incentives given by the company has not been as expected by employees, Suggestions given as material for consideration to the leadership of the company is to improve employee performance, we recommend that a large incentive be added and the provision is based on units of vehicles that have been serviced by employees. asignificant level
\end{abstract}

Keyword: employee incentive and performance

\section{PENDAHULUAN}

Sumber daya manusia merupakan aset perusahaan yang paling penting dalam menentukan berhasil tidaknya suatu perusahaan, karena merekalah yang menggerakkan dan membuat sumber daya lainnya bekerja. Oleh karena itu, perusahaan harus memperhatikan unsur manusia sebagai karyawan dibandingkan sumber daya lainnya.

Insentif merupakan balas jasa tambahan yang diberikan perusahaan kepada karyawan berdasarkan produktivitas kerja masing-masing karyawan. Insentif diberikan kepada karyawan untuk meningkatkan motivasi mereka untuk bekerja, sehingga produktivitas kerjanya diharapkan mengalami peningkatan.

Perusahaan mendorong produktivitas kerja yang lebih tinggi dengan menganut sistem insentif sebagai bagian dari sistem imbalan yang berlaku bagi para karyawan organisasi. Dengan adanya insentif, diharapkan produktivitas kerja karyawan semakin meningkat, karena semakin tinggi produktivitas kerja karyawan, semakin besar insentif yang diberikan sebagai balas jasanya.

Kinerja merupakan keinginan dan kesungguhan karyawan dalam menyelesaikan tugastugas yang dibebankan oleh atasan kepadanya. Kinerja dapat ditingkatkan dengan memenuhi kebutuhan karyawan, karena bila karyawan merasa kebutuhannya terpenuhi, maka kinerjanya meningkat. 
Berikut ini akan disajikan beberapa hasil penelitian tentang Pengaruh Pemberian Insentif terhadap Kinerja Karyawan:

a. Penelitian Mubarak, Mawardi (2014), melakukan penelitian tentang" Pengaruh Pemberian Insentif terhadap Kinerja Karyawan pada PT Kima Makasar. Hasil penelitian tersebut dengan pengujian menggunakan regresi linear sederhana menyimpulkan bahwa koefisien determinasi ( R-Square) sebesar 0,563 artinya sebesar 56,30\% insentif berpengaruh terhadap kinerja dan sisanya sebesar $43,70 \%$ dipengaruhi oleh variabel lain seperti kompensasi, disiplin dan gaya kepemimpinan.

b. Suhendra (2015), melakukan penelitian dengan judul " Analisis Pengaruh pemberian Insentif Terhadap Kinerja Karyawan Pada PT Telkom. Hasil penelitian tersebut menyimpulkan bahwa Koefisien determinasi (R-Square) sebesar 0,521 hal ini menunjukkan bahwa variabel bebas (insentif) tersebut memberikan sumbangan sebesar 52,10 \% terhadap variabel terikat ( kinerja) sedangkan sisanya sebesar $47,90 \%$ dipengaruhi oleh faktor lainnya.

c. Suharyanto (2015) melakukan penelitian tentang " Pengaruh Pemberian Insentif Terhadap Kinerja Karyawan Pada Unit Kerja Produksi di PT Percetakan Rembang Palembang". Hasil penelitian menunjukkan bahwa prngaruh variabel insentif $(X)$ terhadap kinerja karyawan (Y) ditunjukkan oleh nilai Koefisien Determinasi (R-Square) sebesar 0,266. Angka ini menyimpulkan bahwa variabel insentif $(X)$ yg digunakan dalam persamaan regresi linear sederhana memberikan kontribusi terhadap kinerja karyawan(Y) sebesar $26,60 \%$ sedangkan sisanya 73,40\% dipengaruhi oleh faktor lain.

PT. Istana Deli Kencana Medan bergerak di bidang jual beli mobil dan perbengkelan mobil. Kinerja karyawan dapat diukur dari realisasi kendaraan yang diservice oleh tenaga mekanik. Perusahaan memberikan insentif kepada karyawan bagian bengkel. Hal ini diberikan jika tenaga mekanik mampu memperbaiki kendaraan (mobil) di atas standar yang ditetapkan perusahaan yaitu 150 unit/triwulan dan selama setahun sebanyak 600 unit. Jika karyawan mampu menservice kendaraan di atas standar diberikan insentif $\mathrm{Rp}$ 900.000,00/triwulan, dan karyawan yang tidak mampu mencapai standar yang ditetapkan, maka perusahaan tidak memberikan insentif. Kinerja karyawan diukur dari jumlah unit mobil yang diservice. Jumlah karyawan bengkel pada tahun 2016 sebanyak 64 orang. Persentase pencapaian standar kinerja tahun 2016 disajikan pada tabel berikut:

Tabel 1 Persentase Pencapaian Standar Kinerja Karyawan Pada PT. Istana Deli Kencana Medan Tahun 2016

\begin{tabular}{|c|c|c|c|c|}
\hline Triwulan & $\begin{array}{c}\text { Tenaga kerja } \\
\text { (orang) }\end{array}$ & $\begin{array}{c}\text { Standar kerja / } \\
\text { tenaga kerja (unit) }\end{array}$ & $\begin{array}{c}\text { Total standar } \\
\text { kinerja (unit) }\end{array}$ & $\begin{array}{c}\text { Realisasi } \\
\text { kinerja (unit) }\end{array}$ \\
\hline I & 64 & 150 & 9.600 & 8.987 \\
\hline II & 64 & 150 & 9.600 & 9.014 \\
\hline III & 64 & 150 & 9.600 & 9.178 \\
\hline IV & 64 & 150 & 9.600 & 9.233 \\
\hline
\end{tabular}

Sumber: PT. Istana Deli Kencana Medan

Dari Tabel di atas, diketahui bahwa kinerja karyawan PT. Istana Deli Kencana Medan rendah, terlihat dari tidak tercapainya standar kinerja triwulan I sebanyak 613 unit, triwulan II sebanyak 586 unit, triwulan III sebanyak 422 unit dan triwulan IV sebanyak 367 unit. Oleh karena itu, masalah yang akan diteliti adalah: "Bagaimana pengaruh pemberian insentif terhadap kinerja karyawan pada PT. Istana Deli Kencana Medan?" 


\section{TINJAUAN PUSTAKA}

\section{A. Teori Insentif}

Sistem insentif menunjukkan hubungan yang paling jelas antara kompensasi dan prestasi kerja.Hariandja (2002:265), "insentif diartikan sebagai bentuk pembayaran langsung yang didasarkan atau dikaitkan langsung dengan kinerja dan gain sharing, yang juga dikaitkan dengan kinerja dan diartikan sebagai pembagian keuntungan bagi karyawan akibat peningkatan produktivitas atau penghematan biaya".

Menurut Hasibuan (2003:129), teori upah insentif adalah:

1. Piece rate.

a. Upah per potong proporsional. Upah per potong proporsional dibayar berdasarkan produktivitas pekerja dikalikan tarif upah per potong yang didapat dari penyelidikan waktu untuk menentukan waktu standarnya. Sebagai contoh, bila standar ditetapkan sebesar 50 unit per jam, tingkat upah sebesar Rp 500,00 per jam, karyawan memproduksi 600 unit dalam 8 jam sehari, maka tingkat upah per unit sebesar Rp $500,00: 50=\operatorname{Rp} 10,00$ dan penghasilan total $=600 \times \operatorname{Rp~10,00}=6.000,00$. Bila penghasilan setiap jam dijamin tanpa memperhatikan tingkat keluaran $(8$ jam $\times R p 500,00=R p$ $4.000,00)$, penghasilan insentif dalam contoh ini adalah sebesar $R p$ 6.000,00 - Rp $4.000,00=\operatorname{Rp} 2.000,00$.

b. Upah per potong Taylor. Upah per potong Taylor digunakan dengan cara mengatur tarif yang berbeda untuk karyawan yang produktivitasnya tinggi dengan yang produktivitasnya rendah. Mereka yang produktivitasnya tinggi ketika outputnya mencapai standar atau lebih, akan menerima upah per potong lebih besar dari pada karyawan yang bekerja di bawah standar.

c. Upah per potong kelompok. Cara menentukan upah per potong kelompok adalah dengan menentukan standar untuk kelompok. Mereka yang berada di atas standar kelompoknya akan dibayar sebanyak unit yang dihasilkan dikalikan dengan tarif, sedangkan yang berada di bawah standar akan dibayar sebesar jam kerja dikali tarif upah per jamnya.

2. Premi berasarkan waktu yang dihemat meliputi:

Pada halsey plan, persentase premi yang diberikan adalah $50 \%$ dari waktu yang dihemat, dengan anggapan bahwa tidak ada standar kerja yang akurat sekali. Contoh, bila waktu standar 12 jam diselesaikan dalam 8 jam, karyawan menerima upah $(8 \times R p 500,00=R p$ $4.000,00$ pluas $50 \%$ waktu yang dihemat $(4 \mathrm{jam} \times \operatorname{Rp} 500,00=\operatorname{Rp} 1.000,000=\operatorname{Rp} 5.000,00$. Bila dapat ditetapkan standar secara akurat persentase bonus hendaknya naik sampai $100 \%$, yang berarti identik dengan rencana atas dasar unit keluaran langsung.

3. Premi berdasarkan waktu pengerjaan

a) Rowan plan. Pada rowan plan, premi yang didapat adalah selisih antara hasil standar dengan hasil aktual dibagi dengan hasil aktual dikalikan jam kerja dan upah. Indeks efisiensi dihitung melalui pembagian waktu yang dihemat dengan waktu standar yaitu 4 jam dibagi 12 jam $=33,33 \%$. Persentase bonus ini kemudian dikalikan dengan nilai waktu pengerjaan. Jadi, karyawan menerima upah (8 jam $\times \operatorname{Rp} 500,00=\operatorname{Rp} 4.000,00)$ plus 33,33\% x Rp 4.000,00 = Rp 1.333,20 sama dengan $\operatorname{Rp~5.333,20.~Ini~berarti~karyawan~}$ tidak mungkin menerima upah dua kali lipat.

b) Emerson plan. Pada cara ini, perusahaan membuat tabel indeks efisiensi sesuai dengan kebijakan perusahaan. Misalnya, bila 12 jam standar telah diselesaikan selama 8 jam sehari, karyawan tidak hanya menerima $(2 \times \operatorname{Rp} 500,00=\operatorname{Rp} 6.000,00)$, tetapi juga bonus sebesar $10 \%$ dari nilai waktu standar $(10 \% \times 6.000,00=R p \quad 6000,00)$, sehingga penghasilan total $\mathrm{Rp} 6.600,00$. Bila 8 jam standar tidak dicapai, tidak ada bonus. Rencana ini digunakan bila standar-standar sangat penting untuk dicapai dan manajemen memerlukan suatu bentuk insentif yang kuat. 
Volume 19 Nomor 1 berupa:

Menurut Siagian (2002:269), insentif yang diberikan kepada karyawan juga dapat

1. Bonus

Insentif dalam bentuk bonus diberikan pada karyawan yang mampu bekerja sedemikian rupa, sehingga tingkat produksi yang baku terlampaui. Melampaui tingkat produksi itu dapat dalam salah satu dari tiga bentuk, pertama berdasarkan jumlah unit produksi yang dihasilkan dalam satu kurun waktu tertentu.

Sistem insentif lain yang lumrah ditetapkan adalah pemberian komisi. Pada dasarnya ada dua bentuk sistem ini. Pertama, para karyawan memperoleh gaji pokok, tetapi penghasilannya dapat bertambah dengan bonus yang diterimanya karena keberhasilan melaksanakan tugas. Kedua, karyawan memperoleh penghasilan semata-mata berupa komisi. Cara kedua ini paling sering diterapkan bagi tenaga penjuaaln di perusahaan tertentu seperti penjualan kendaraan bermotor dan real estate.

2. Insentif bagi eksekutif.

Bentuk insentif bagi para eksekutif tersebut dapat beraneka ragam pula. Misalnya, para manajer yang relatif muda sangat mungkin mendambakan insentif finansial berupa bonus tunai karena penghasilan ekstra itu mereka butuhkan untuk membiayai kebutuhan keluarga.

Menurut Mathis dan Jackson (2002: 183), sistem insentif organisasi adalah:

Bagi hasil. Program bagi hasil dapat dimulai oleh manajer dengan mengidentifikasi cara-cara yang diperlukan di mana peningkatan produktivitas, kualitas dan kinerja finansial dapat terjadi dan memutuskan bahwa beberapa hasil tadi haruslah dibagi-bagi dengan para karyawan. Langkah yang paling kritis adalah melibatkan karyawan yang seluruh tingkat pekerjaan dalam proses bagi hasil ini, kadangkala dengan membentuk satuan tugas yang khusus menangani bagi hasil ini, yang terdiri dari para manajer maupun non manajer. Bagitu satuan tugas terbentuk, maka ada dua keputusan penting yang dharus dibuat: 1) bagaimana hasil itu akan dibagi antara karyawan, dan 2) pengukuran kinerja apa yang akan digunakan. Program bagi hasil terdiri dari:

a. Program improshare. Improshare merupakan singkatan dari Improved Productivity (produktivitas yang meningkat), yâng diciptakan oleh Mitchell Fein, seorang ahli teknik industri. Sebuah standar kemudian diukur, dan bonus mingguan dibayarkan berdasarkan tingkatan di mana standar itu ternyata dilampaui.

b. Program Scanlon. Konsep dasar yang ditekankan oleh program Scanlon adalah bahwa efisiensi tergantung dari kerja kelompok dan kerja sama di seluruh perusahaan. Persentase yang telah ditetapkan dari dana ini kemudian dibagi antara karyawan dengan organisasi.

c. Program Rucker. Program Rucker diperkenalkan oleh Allan W. Rucker pada tahun 1930 sebagai seorang ekonom. formula Rucker ini mengenalkan kepada variabel ketiga, yaitu nilai uang dari seluruh bahan baku, persediaan dan jasa yang digunakan organisasi. Formulanya adalah:

$\frac{\text { Nilai tenaga kerja }}{\text { Nilai produksi - Nilai bahan baku, persediaan dan jasa }}$

Hasilnya dinamakan nilai tambah terhadap sebuah produk yang dihasilkan perusahaan.

\section{B. Kinerja Karyawan}

Kinerja merupakan hasil pelaksanaan pekerjaan yang dicapai seorang pegawai dalam melaksanakan tugas yang dibebankan kepadanya. Ciri-ciri karyawan yang berkinerja terbaik antara lain: menguasai seluk beluk bidang tugas dan bidang lain yang terkait, mempunyai ketrampilan, melaksanakan tugas secara berdaya guna dan berhasil guna dan hasil pekerjaannya melebihi yang dituntut organisasi.

Menurut Simanjuntak (2005:10), kinerja karyawan dipengaruhi oleh banyak faktor yang dapat digolongkan pada tiga kelompok, yaitu: 
1. Kompetensi individu. Kompetensi individu adalah kemampuan dan ketrampilan melakukan kerja. Kompetensi setiap orang dipengaruhi oleh beberapa faktor, yaitu: Kemampuan.
a. Pendidikan dan pelatihan.
b. Pengalaman kerja
c. Motivasi dan etos kerja

2. Dukungan organisasi. Prestasi kerja karyawan juga tergantung pada dukungan organisasi dalam bentuk:
a. Pengorganisasi
b. Penyadiaan sarana dan prasarana kerja
c. Kondisi Kerja
d. Syarat kerja

3. Dukungan manajemen.
a. Kepemimpinan.
b. Penghargaan

\section{Pengaruh Pemberian Insentif Terhadap Kinerja Karyawan}

Untuk meningkatkan kinerja karyawan, perusahaan memberikan insentif yang berfungsi untuk memotivasi mereka dalam menyelesaikan tugas-tugas yang dibebankan oleh atasan. Menurut Handoko (2002:176), "sistem insentif menunjukkan hubungan yang paling jelas antara kompensasi dan kinerja". Sistem insentif umumnya digunakan untuk menggambarkan rencana-rencana pembayaran upah yang dikaitkan langsung dengan berbagai standar prestasi kerja. Dalam pemberian insentif tersebut, perusahaan perlu menetapkan standar kerja yang harus diselesaikan oleh masing-masing karyawan. Jika karyawan mampu mencapai standar yang ditetapkan, maka perusahaan tidak memberikan insentif. Akan tetapi, jika karyawan mampu menyelesaikan suatu pekerjaan di atas standar yang ditetapkan, maka diberikan insentif kepada karyawan. Dengan adanya insentif, diharapkan kinerja karyawan semakin meningkat.

\section{METODE PENELITIAN}

\section{A. Populasi dan Sampel}

Populasi pada penelitian ini adalah insentif dan jumlah kendaraan yang diservice karyawan PT. Istana Deli Kencana Medan mulai berdiri tahun 1983 - 2016. Sampel merupakan sebagian dari anggota populasi, maka yang menjadi sampel penelitian adalah insentif dan jumlah kendaraan yang diservice oleh 64 orang tenaga mekanik tahun 2016. Teknik penentuan sampel adalah convinience random sampling, yaitu pengambilan sampel dipermudah.

\section{B. Operasionalisasi Variabel.}

Definisi operasionalisasi variabel yang diteliti adalah:

1. Variabel bebas adalah insentif $(X)$, yaitu balas jasa yang diberikan kepada karyawan jika mampu melakukan service kendaraan di atas standar yang ditetapkan perusahaan. Indikator pengukurannya adalah besar insentif yang diberikan oleh perusahaan tahun 2016. Skala pengukurannya adalah skala rasio dalam satuan rupiah.

2. Variabel terikat (Y) adalah kinerja pegawai, yaitu kesungguhan karyawan dalam menyelesaikan tugas-tugas yang dibebankan oleh perusahaan. Indikator pengukurannya adalah realisasi jumlah kendaraan yang diservice oleh tenaga mekanik. Skala pengukurannya adalah skala rasio dalam satuan unit.

\section{Teknik Pengumpulan Data}

Pada penelitian ini digunakan data Sekunder melalui dokumentasi 


\section{Metode Analisis.}

Teknik analisis data yang digunakan adalah regresi linier sederhana yang berguna untuk mengetahui pengaruh pemberian insentif terhadap kinerja karyawan dengan menggunakan rumus (Supranto, 2001:236):

$$
Y=\propto+\beta X+\varepsilon i
$$

Nilai $\propto$ dan $\beta$ dihitung dengan menggunakan rumus:

$$
\alpha=\bar{Y}-b \bar{X} \quad \beta=\frac{n \sum X Y-\sum X \sum Y}{n \sum X^{2}-\left(\sum X\right)^{2}}
$$
1

Keterangan: $\mathrm{Y}=$ Kinerja karyawan

$\mathrm{X}=$ Pemberian insentif

$\mathrm{a}_{0}=$ Konstanta

$\beta_{i}=$ Koefisien regresi

ei $=$ Tingkat kesalahan estimasi

Selanjutnya, digunakan analisis korelasi untuk mengetahui keeratan hubungan antara pemberian insentif dengan kinerja karyawan, dengan rumus:

$$
r_{X Y}=\frac{n \sum X Y-\left(\sum X\right)\left(\sum Y\right)}{\sqrt{\left\{n \sum X^{2}-\left(\sum X\right)^{2}\right\}\left\{n \sum Y^{2}-\left(\sum Y\right)^{2}\right\}}}
$$

Keterangan : $r_{x y}=$ koefisien korelasi dan $n=$ jumlah sampel

Untuk mengetahui sejauh mana kinerja karyawan dapat dijelaskan oleh pemberian insentif, ditentukan dari koefisien determinasi dengan rumus:

$\mathrm{D}=\mathrm{r}^{2}$

Pembuktian hipotesis dilakukan dengan menggunakan statistik uji z, dengan prosedur sebagai berikut:

1. $\mathrm{H}_{0}: \beta \mathrm{i}=0$, artinya pemberian insentif tidak berpengaruh signifikan terhadap kinerja karyawan pada PT. Istana Deli Kencana Medan.

$\mathrm{H}_{1}: \beta \mathrm{i}>0$, artinya pemberian insentif berpengaruh signifikan terhadap kinerja karyawan pada PT. Istana Deli Kencana Medan.

2. Jumlah sampel $=64$ orang

Level of significan $(\alpha)=5 \%$

3. Uji statistik z: $z=\frac{\beta_{i}}{S_{e \beta i}}$

Keterangan: $\mathrm{z}=\mathrm{z}_{\text {hitung, }} \beta \mathrm{i}=$ koefisien regresi dan $\mathrm{S}_{\mathrm{e} \beta \mathrm{i}}=$ standar error koefisien regresi.

4. Kriteria pengujian: $\mathrm{H}_{0}$ diterima jika $\mathrm{Z}_{\text {hitung }} \leq \mathrm{z} \propto$ dan $\mathrm{H}_{1}$ diterima jika $\mathrm{Z}_{\text {hitung }}>\mathrm{z} \propto$

Pengujian yang digunakan adalah diuji dengan menggunakan program SPSS (Statistical Program of Social Sciences). Versi 20,0

\section{HASIL DAN PEMBAHASAN}

PT. Istana Deli Kencana Medan berdiri pada tanggal 1 Juli 1983 yang berlokasi di Jl. H. Adam Malik No. 85 Medan. PT. Istana Deli Kencana Medan pada mulanya bergabung dengan CV. Indako di Jl. Pemuda Medan, kemudian menarik diri dan berdiri sendiri. PT. Istana Deli Kencana Medan ini adalah sub dealer langsung dari PT. Imora Motor di Jakarta. Dalam beberapa tahun kemudian, PT. Istana Deli Kencana Medan ini adalah dealer utama Mobil Honda di Medan mengalami perkembangan dan kemajuan yang sangat pesat. Dengan semakin banyaknya permintaan jenis mobil Honda, perusahaan member memberikan pelayanan sesuai kemampuannya. Selain penjualan mobil, PT. Istana Deli Kencana Medan juga memberi pelayanan jasa perbengkelan. 


\section{A. Pemberian Insentif}

PT. Istana Deli Kencana Medan merupakan salah satu perusahaan yang bergerak di bidang penjualan dan perbengkelan mobil. Untuk meningkatkan semangat kerja tenaga mekanik, perusahaan memberikan insentif. Untuk meningkatkan kemampuan tenaga mekanik, PT. Istana Deli Kencana Medan menyelenggarakan pelatihan kepada seluruh tenaga mekanik. Hal ini dilakukan karena setiap tahun kendaraan (mobil) mengalami perubahan spesifikasi mesin sesuai perkembangan teknologi. Dengan adanya pelatihan tersebut, perusahaan mengharapkan standar kerja yang ditetapkan dapat tercapai.

PT. Istana Deli Kencana Medan hanya memberikan insentif kepada tenaga mekanik yang mampu memperbaiki mobil di atas standar yang ditetapkan sebanyak 150 unit/triwulan. Jika jumlah kendaraan yang dapat diperbaiki oleh tenaga mekanik di bawah standar yang ditetapkan, tidak mendapatkan insentif. Tenaga mekanik yang mampu mencapai standar kerja diberikan insentif sebesar Rp 900.000,00/triwulan. Jenis insentif yang diberikan PT. Istana Deli Kencana Medan kepada tenaga mekanik adalah upah per potong Taylor, artinya tenaga mekanik mendapatkan insentif jika mampu mencapai standar kerja yang ditetapkan perusahaan. Pembayaran insentif dilakukan bersamaan dengan pembayaran gaji karyawan setiap awal bulan.

Tabel 2. Insentif yang Diberikan Kepada Tenaga Mekanik Pada PT. Istana Deli Kencana Medan Tahun 2016 (dalam rupiah)

\begin{tabular}{|l|l|c|c|c|c|r|}
\hline \multirow{2}{*}{ Nama } & \multicolumn{2}{|c|}{ Insentif (Rp) } & \multirow{2}{*}{ Total } \\
\cline { 3 - 7 } & & I & II & III & IV & \\
\hline \hline 1 & Bahrum & 900.000 & - & 900.000 & 900.000 & $2.700 .000,00$ \\
\hline 2 & Misman & - & 900.000 & - & 900.000 & $1.800 .000,00$ \\
\hline 3 & Ismail & 900.000 & - & 900.000 & - & $1.800 .000,00$ \\
\hline 4 & Ahmad Dedi Fauzi & - & - & - & 900.000 & $900.000,00$ \\
\hline 5 & Ricky Hardiansyah & 900.000 & 900.000 & - & - & $1.800 .000,00$ \\
\hline 6 & Ismed Daniel & - & - & - & 900.000 & $900.000,00$ \\
\hline 7 & Ismail Damanik & - & 900.000 & - & - & $900.000,00$ \\
\hline 8 & Reza Nurmansyah & 900.000 & - & 900.000 & - & $1.800 .000,00$ \\
\hline 9 & Suratmanto & - & - & 900.000 & - & $900.000,00$ \\
\hline 10 & Seriadi & - & - & 900.000 & - & $900.000,00$ \\
\hline 11 & Irwansyah & 900.000 & - & - & - & $900.000,00$ \\
\hline 12 & Misman N. & 900.000 & - & 900.000 & 900.000 & $2.700 .000,00$ \\
\hline 13 & Azhari S & 900.000 & - & 900.000 & 900.000 & $2.700 .000,00$ \\
\hline 14 & Hasan Basri & 900.000 & - & 900.000 & - & $1.800 .000,00$ \\
\hline 15 & Irwanto & - & 900.000 & - & - & $900.000,00$ \\
\hline 16 & Asmui & - & - & 900.000 & & $900.000,00$ \\
\hline 17 & Rudian & - & - & - & 900.000 & $900.000,00$ \\
\hline 18 & Hendri Syahputra & - & 900.000 & & 900.000 & $1.800 .000,00$ \\
\hline 19 & Iwan Syahputra & - & - & 900.000 & 900.000 & $1.800 .000,00$ \\
\hline 20 & Suharman & 900.000 & 900.000 & 900.000 & - & $2.700 .000,00$ \\
\hline 21 & Dian Wahyudi & 900.000 & 900.000 & 900.000 & 900.000 & $3.600 .000,00$ \\
\hline 22 & Mirza Novani & 900.000 & - & - & - & $900.000,00$ \\
\hline 23 & Aidil Fazri & 900.000 & - & - & 900.000 & $1.800 .000,00$ \\
\hline 24 & Rahmat Tomas & - & 900.000 & - & - & $900.000,00$ \\
\hline 25 & Agus Tono & - & 900.000 & - & - & $900.000,00$ \\
\hline 26 & Awal Utomo & - & - & 900.000 & 900.000 & $1.800 .000,00$ \\
\hline 27 & Kho Tie Tjun & - & - & - & 900.000 & $900.000,00$ \\
\hline
\end{tabular}


Volume 19 Nomor 1

\begin{tabular}{|c|c|c|c|c|c|c|}
\hline & \multirow{2}{*}{ Nama } & \multicolumn{4}{|c|}{ Insentif (Rp) } & \multirow{2}{*}{ Total } \\
\hline & & I & II & III & IV & \\
\hline 28 & Hariyadi & - & - & 900.000 & 900.000 & $1.800 .000,00$ \\
\hline 29 & Dian Nurhadi & - & - & 900.000 & - & $900.000,00$ \\
\hline 30 & Ahmad Asnan B. & - & 900.000 & 1900.000 & 900.000 & $2.700 .000,00$ \\
\hline 31 & Hendra Winata & 900.000 & 900.000 & - & 900.000 & $2.700 .000,00$ \\
\hline 32 & Riki Adi Putra & - & 900.000 & 900.000 & - & $1.800 .000,00$ \\
\hline 33 & Sri Irmayani & - & 900.000 & - & - & $900.000,00$ \\
\hline 34 & David Pangeran S. & - & 900.000 & - & 900.000 & $1.800 .000,00$ \\
\hline 35 & Susmidar & 900.000 & - & 900.000 & 900.000 & $2.700 .000,00$ \\
\hline 36 & Desil Afrizal & - & 900.000 & - & - & $900.000,00$ \\
\hline 37 & Faijaria & - & - & - & 900.000 & $900.000,00$ \\
\hline 38 & Wawan Kurniawan & 900.000 & - & - & 900.000 & $1.800 .000,00$ \\
\hline 39 & Ibnu Utama & - & TTTT & - & 900.000 & $900.000,00$ \\
\hline 40 & Bambang Sumatri & -12 & 900.000 & & 900.000 & $1.800 .000,00$ \\
\hline 41 & Ramadani & 900.000 & - & -2 & - & $900.000,00$ \\
\hline 42 & Irwansyah N. & 900.000 & 900.000 & 900.000 & 900.000 & $3.600 .000,00$ \\
\hline 43 & M. Idham Lubis & 900.000 & - & $-\quad 1$ & - & $900.000,00$ \\
\hline 44 & Saiful Amri & 900.000 & - & - & 900.000 & $1.800 .000,00$ \\
\hline 45 & Iswan Sutrisno & - & - & - & 900.000 & $900.000,00$ \\
\hline 46 & Lukman Indrawan & - & - & - & 900.000 & $900.000,00$ \\
\hline 47 & Mariadi & - & - & 900.000 & - & $900.000,00$ \\
\hline 48 & Rimson Situngkir & 900.000 & -1 & 900.000 & - & $1.800 .000,00$ \\
\hline 49 & Dedi Maulana & - & 900.000 & - & - & $900.000,00$ \\
\hline 50 & Khairul Azwar D. & - & - & 900.000 & 900.000 & $1.800 .000,00$ \\
\hline 51 & Hendra Kumala & - & 900.000 & 900.000 & 900.000 & $2.700 .000,00$ \\
\hline 52 & Juanda P. & $S_{x}-$ & 900.000 & $-\sqrt{2}$ & 900.000 & $1.800 .000,00$ \\
\hline 53 & Jufri P.H. & 900.000 & 900.000 & $\sqrt{1}-$ & 900.000 & $2.700 .000,00$ \\
\hline 54 & Ismail Nasution & $-\sqrt{C}$ & TOI-IK & - & 900.000 & $900.000,00$ \\
\hline 55 & Ahmad Hidayat & - & - & 900.000 & - & $900.000,00$ \\
\hline 56 & Iskandarsyah & 900.000 & - & - & 900.000 & $1.800 .000,00$ \\
\hline 57 & Arjunanta Purba & - & - & 900.000 & - & $900.000,00$ \\
\hline 58 & Muhammad K. & 900.000 & - & - & 900.000 & $1.800 .000,00$ \\
\hline 59 & Togu Tuturena & 900.000 & - & - & 900.000 & $1.800 .000,00$ \\
\hline 60 & Supryandi & - & 900.000 & - & - & $900.000,00$ \\
\hline 61 & Doni Adtya P. & - & - & 900.000 & - & $900.000,00$ \\
\hline 62 & Brian Nicky D. & 900.000 & - & - & 900.000 & $1.800 .000,00$ \\
\hline 63 & Ilham & - & 900.000 & - & 900.000 & $1.800 .000,00$ \\
\hline 64 & Andy & 900.000 & 900.000 & 900.000 & 900.000 & $3.600 .000,00$ \\
\hline
\end{tabular}

Sumber: PT. Istana Deli Kencana Medan

Berdasarkan tabel tersebut, diketahui bahwa dari 64 orang tenaga mekanik yang mencapai standar kerja dan menerima insentif pada triwulan I sebanyak 26 orang dengan insentif yang diterima sebesar Rp 23.400.000,00. Pada triwulan II, dari 64 orang tenaga mekanik yang mencapai standar kerja dan menerima insentif sebanyak 24 orang dengan insentif yang diterima sebesar Rp 21.600.000,00. Pada triwulan III, dari 64 orang tenaga mekanik yang mencapai standar kerja dan menerima insentif sebanyak 27 orang dengan jumlah insentif yang diterima sebesar Rp 24.300.000,00. Pada triwulan III, dari 64 orang tenaga mekanik yang mencapai standar kerja dan menerima insentif sebanyak 37 orang dengan 
Volume 19 Nomor 1

jumlah insentif yang diterima sebesar Rp 33.300.000,00. Dilihat dari data tersebut terlihat bahwa karyawan yang tidak menerima insentif pada triwulan I sebanyak 38 orang, triwulan II sebanyak 40 orang, triwulan III sebanyak 27 orang dan triwulan IV sebanyak 37 orang. Karyawan yang tidak mendapatkan insentif menunjukkan bahwa kinerja karyawan tersebut rendah.

\section{B. Kinerja Karyawan}

Kinerja karyawan menunjukkan kesungguhan karyawan dalam menyelesaikan tugastugas yang dibebankan oleh atasan. Tenaga mekanik yang mampu mencapai standar jumlah kendaraan yang harus diservice merasa puas, selain mendapatkan insentif juga diberikan kesempatan untuk menduduki jabatan yang lebih tinggi. Misalnya, tenaga mekanik dapat dipromosikan menjadi kepala bagian mekanik dan manager perbengkelan. Akan tetapi, besar insentif yang diberikan perusahaan belum sesuai yang diharapkan oleh karyawan.

Realisasi kendaraan yang diservice oleh karyawan pada PT. Istana Deli Kencana Medan tahun 2016 seperti yang disajikan pada Tabel 3

Tabel 3 Realisasi Kendaraan yang Diservice Karyawan Pada PT. Istana Deli Kencana Medan Tahun 2016 (dalam Rupiah)

\begin{tabular}{|c|c|c|c|c|c|c|c|}
\hline \multirow[t]{2}{*}{ No. } & \multirow{2}{*}{ Nama } & \multirow{2}{*}{$\begin{array}{l}\text { Standar kerja / } \\
\text { tenaga kerja (unit) }\end{array}$} & \multicolumn{4}{|c|}{$\begin{array}{l}\text { Realisasi kendaraan yang } \\
\text { diservice (unit) }\end{array}$} & \multirow{2}{*}{$\begin{array}{l}\text { Total } \\
\text { (unit) }\end{array}$} \\
\hline & & & I & II & III & IV & \\
\hline 1 & Bahrum & 150 & 162 & 130 & 164 & 160 & $\overline{616}$ \\
\hline 2 & Misman & 150 & 118 & 154 & 144 & 157 & 573 \\
\hline 3 & Ismail & 150 & 157 & 147 & 154 & 148 & 606 \\
\hline 4 & Ahmad Dedi Fauzi & 150 & 147 & 140 & 130 & 152 & 569 \\
\hline 5 & Ricky Hardiansyah & 150 & 160 & 151 & 143 & 132 & 586 \\
\hline 6 & Ismed Daniel & 150 & 137 & 145 & 125 & 153 & 560 \\
\hline 7 & Ismail Damanik & 150 & 97 & 153 & 95 & 100 & 445 \\
\hline 8 & Reza Nurmansyah & 150 & 152 & 144 & 152 & 137 & 585 \\
\hline 9 & Suratmanto & A150LIK $S$ & 123 & 132 & 160 & 145 & 560 \\
\hline 10 & Seriadi & 150 & 145 & 125 & 153 & 147 & 570 \\
\hline 11 & Irwansyah & 150 & 156 & 137 & 140 & 149 & 582 \\
\hline 12 & Misman N. & 150 & 164 & 135 & 152 & 163 & 614 \\
\hline 13 & Azhari S & 150 & 155 & 132 & 152 & 163 & 602 \\
\hline 14 & Hasan Basri & 150 & 150 & 142 & 156 & 142 & 590 \\
\hline 15 & Irwanto & 150 & 137 & 153 & 130 & 140 & 560 \\
\hline 16 & Asmui & 150 & 84 & 134 & 152 & 110 & 480 \\
\hline 17 & Rudian & 150 & 102 & 138 & 133 & 157 & 530 \\
\hline 18 & Hendri Syahputra & 150 & 142 & 157 & 98 & 160 & 557 \\
\hline 19 & Iwan Syahputra & 150 & 145 & 145 & 150 & 154 & 594 \\
\hline 20 & Suharman & 150 & 165 & 160 & 160 & 143 & 628 \\
\hline 21 & Dian Wahyudi & 150 & 167 & 150 & 166 & 164 & 647 \\
\hline 22 & Mirza Novani & 150 & 170 & 145 & 103 & 140 & 558 \\
\hline 23 & Aidil Fazri & 150 & 162 & 133 & 145 & 154 & 594 \\
\hline 24 & Rahmat Tomas & 150 & 143 & 154 & 132 & 137 & 566 \\
\hline 25 & Agus Tono & 150 & 98 & 152 & 140 & 140 & 530 \\
\hline 26 & Awal Utomo & 150 & 136 & 142 & 156 & 150 & 584 \\
\hline 27 & Kho Tie Tjun & 150 & 130 & 134 & 145 & 163 & 572 \\
\hline 28 & Hariyadi & 150 & 123 & 137 & 163 & 164 & 587 \\
\hline
\end{tabular}


Volume 19 Nomor 1

\begin{tabular}{|c|c|c|c|c|c|c|c|}
\hline \multirow[t]{2}{*}{ No. } & \multirow[t]{2}{*}{ Nama } & \multirow{2}{*}{$\begin{array}{c}\text { Standar kerja / } \\
\text { tenaga kerja (unit) }\end{array}$} & \multicolumn{4}{|c|}{$\begin{array}{l}\text { Realisasi kendaraan yang } \\
\text { diservice (unit) }\end{array}$} & \multirow{2}{*}{$\begin{array}{l}\text { Total } \\
\text { (unit) }\end{array}$} \\
\hline & & & I & II & III & IV & \\
\hline 29 & Dian Nurhadi & 150 & 125 & 140 & 154 & 142 & 561 \\
\hline 30 & Ahmad Asnan B. & 150 & 100 & 155 & 156 & 154 & 565 \\
\hline 31 & Hendra Winata & 150 & 154 & 157 & 147 & 171 & 629 \\
\hline 32 & Riki Adi Putra & 150 & 148 & 150 & 158 & 94 & 550 \\
\hline 33 & Sri Irmayani & 150 & 145 & 160 & 135 & 130 & 570 \\
\hline 34 & David Pangeran S. & 150 & 94 & 153 & 144 & 160 & 551 \\
\hline 35 & Susmidar & 150 & 155 & 137 & 156 & 154 & 602 \\
\hline 36 & Desil Afrizal & 150 & 132 & 157 & 147 & 98 & 534 \\
\hline 37 & Faijaria & 150 & 147 & 145 & 100 & 163 & 555 \\
\hline 38 & Wawan Kurniawan & 150 & 156 & 144 & 130 & 160 & 590 \\
\hline 39 & Ibnu Utama & 150 & 130 & 143 & 127 & 152 & 552 \\
\hline 40 & Bambang Sumatri & 150 & 98 & 152 & 134 & 155 & 539 \\
\hline 41 & Ramadani & 150 & 164 & 132 & 145 & 110 & 551 \\
\hline 42 & Irwansyah N. & 150 & 162 & 154 & 154 & 151 & 621 \\
\hline 43 & M. Idham Lubis & 150 & 166 & 132 & 144 & 143 & 585 \\
\hline 44 & Saiful Amri & 150 & 154 & 145 & 140 & 160 & 599 \\
\hline 45 & Iswan Sutrisno & 150 & 143 & 84 & 130 & 152 & 509 \\
\hline 46 & Lukman Indrawan & 150 & 147 & 146 & 140 & 154 & 587 \\
\hline 47 & Mariadi & 150 & 146 & 132 & 167 & 98 & 543 \\
\hline 48 & Rimson Situngkir & 150 & 152 & 146 & 175 & 80 & 553 \\
\hline 49 & Dedi Maulana & 150 & 143 & 156 & 123 & 142 & 564 \\
\hline 50 & Khairul Azwar D. & 150 & 137 & 70 & 165 & 153 & 525 \\
\hline 51 & Hendra Kumala & 150 & 132 & 150 & 154 & 157 & 593 \\
\hline 52 & Juanda P. & 150 & 94 & 159 & 142 & 160 & 555 \\
\hline 53 & Jufri P.H. & 150 & 152 & 157 & 123 & 157 & 589 \\
\hline 54 & Ismail Nasution & KA150 TIKS & 144 & 75 & 144 & 154 & 517 \\
\hline 55 & Ahmad Hidayat & 150 & 132 & 123 & 154 & 142 & 551 \\
\hline 56 & Iskandarsyah & 150 & 154 & 142 & 132 & 154 & 582 \\
\hline 57 & Arjunanta Purba & 150 & 133 & 134 & 167 & 98 & 532 \\
\hline 58 & Muhammad K. & 150 & 162 & 140 & 148 & 164 & 614 \\
\hline 59 & Togu Tuturena & 150 & 164 & 145 & 142 & 156 & 607 \\
\hline 60 & Supryandi & 150 & 98 & 157 & 144 & 97 & 496 \\
\hline 61 & Doni Adtya P. & 150 & 147 & 90 & 159 & 125 & 521 \\
\hline 62 & Brian Nicky D. & 150 & 155 & 144 & 100 & 152 & 551 \\
\hline 63 & Ilham & 150 & 132 & 153 & 145 & 154 & 584 \\
\hline 64 & Andy & 150 & 163 & 154 & 160 & 163 & 640 \\
\hline
\end{tabular}

Sumber: PT. Istana Deli Kencana Medan

Dari data yang disajikan pada tabel 3, dapat dihitung jumlah standar yang tidak tercapai, sebagai berikut:

Triwulan I = Standar kinerja - Realisasi kendaraan y ang diservice

$$
\begin{aligned}
& =9.600 \text { unit }-8.987 \text { unit } \\
& =613 \text { unit atau meny impang } 6,39 \%
\end{aligned}
$$


Volume 19 Nomor 1

Triwulan II $=9.600$ unit -9.014 unit

$=586$ unit atau menyimpang $6,10 \%$

Triwulan III $=9.600$ unit -9.178 unit

$=422$ unit atau meny imp ang $4,40 \%$

Triwulan IV $=9.600$ unit -9.233 unit

$=367$ unit atau menyimpang $3,82 \%$

Dari perhitungan tersebut terlihat bahwa pada triwulan I penyimpangan antara total standar kinerja dengan realisasi kendaraan yang diservice sebanyak 613 unit (6,39\%), dimana realisasi kendaraan yang diservice lebih rendah dari standar kinerja yang ditetapkan. Dan seterusnya pada triwulan II, hal ini terlihat bahwa total standar kinerja yang ditetapkan perusahaan tidak tercapai dan ini membuktikan bahwa kinerja karyawan rendah karena besar insentif yang diberikan perusahaan belum sesuai harapan karyawan.

\section{Pengujian Hipotesis}

Teknik analisis data yang digunakan adalah analisis regresi linear sederhana yang berguna untuk mengetahui pengaruh pemberian insentif terhadap kinerja karyawan.

Tabel 4. Model Summary

\begin{tabular}{|l|r|r|r|r|}
\hline Model & R & R Square & Adjusted R Square & Std. Error of the Estimate \\
\hline 1 & $0,693(a)$ & 0,481 & 0,472 & 27,15724 \\
\hline
\end{tabular}

a Predictors: (Constant), $\mathrm{X}$

Dari tabel di atas, diketahui nilai koefisien korelasi (R) sebesar 0,693, artinya pemberian insentif mempunyai hubungan yang cukup kuat dan positif terhadap kinerja karyawan pada PT. Istana Deli Kencana Medan Nilai koefisien determinan $\left(R^{2}\right)$ sebesar 0,481. Artinya, kinerja karyawan dapat dijelaskan oleh pemberian insentif sebesar $48,1 \%$ sedangkan $51,9 \%$ lagi dijelaskan oleh faktor lain, seperti promosi jabātän.

Tabel 5. Coefficients(a)

\begin{tabular}{|rl|r|r|r|r|r|}
\hline \multirow{2}{*}{ Model } & \multicolumn{2}{|c|}{$\begin{array}{c}\text { Unstandardized } \\
\text { Coefficients }\end{array}$} & $\begin{array}{c}\text { Standardized } \\
\text { Coefficients }\end{array}$ & \multirow{2}{*}{$\mathbf{z}$} & \multirow{2}{*}{ Sig. } \\
\cline { 3 - 4 } & \multicolumn{1}{|c|}{ B } & \multicolumn{1}{c|}{ Std. Error } & \multicolumn{1}{c|}{ Beta } & & \\
\hline 1 & (Constant) & 515,462 & 7,834 & & 65,795 & 0,000 \\
& $X$ & 0,033 & 0,004 & 0,693 & 7,574 & 0,000 \\
\hline
\end{tabular}

a Dependent Variable: $\mathrm{Y}$

Dari tabel 5, diketahui persamaan regresi linear sederhana adalah $\mathrm{Y}=515,462+$ 0,033X. Artinya, pemberian insentif berpengaruh positif terhadap kinerja karyawan pada PT. Istana Deli Kencana Medan. Hal ini dapat dilihat dari nilai koefisien regresinya yang bertanda positif. Dengan kata lain, bahwa semakin besar insentif yang diberikan kepada karyawan yang memiliki kinerja melebihi standar yang ditetapkan, maka kinerja karyawan semakin tinggi.

Dilihat dari uji $\mathrm{z}$, diperoleh nilai $\mathrm{z}$ hitung sebesar 7,574 dengan tingkat signifikansi sebesar $0,000<$ tingkat signifikan $(\alpha)=0,05$, sehingga $\mathrm{H}_{0}$ ditolak dan $\mathrm{H}_{1}$ diterima. Artinya, pemberian insentif berpengaruh signifikan terhadap kinerja karyawan pada PT. Istana Deli Kencana Medan. 


\section{Pembahasan}

PT. Istana Deli Kencana Medan memberikan insentif kepada para karyawan yang mampu menservice kendaraan di atas standar yang ditetapkan perusahaan. Jenis insentif yang diberikan berupa uang dan pemberiannya didasarkan atas waktu yang dihemat untuk menyelesaikan pekerjaan yang dibebankan oleh atasan kepada tenaga mekanik. Dalam hal ini, tenaga mekanik yang mampu mencapai atau melebihi standar yang ditetapkan, perusahaan memberikan insentif sebesar Rp 900.000,00/triwulan.

Dari tabel 2 dan tabel 3 , diketahui bahwa pada triwulan I, dari 64 orang tenaga mekanik hanya 26 orang yang diberikan insentif sebesar Rp 23.400.000,00 dan terdapat 38 tenaga mekanik yang tidak mampu mencapai standar kerja yang ditetapkan. Pada triwulan II, dari 64 orang tenaga mekanik hanya 24 orang yang diberikan insentif sebesar Rp 21.600.000,00 dan terdapat 40 tenaga mekanik yang tidak mampu mencapai standar kerja yang ditetapkan. Pada triwulan III, dari 64 orang tenaga mekanik hanya 27 orang yang diberikan insentif sebesar Rp 24.300.000,00 dan terdapat 37 tenaga mekanik yang tidak mampu mencapai standar kerja yang ditetapkan. Pada triwulan IV, dari 64 orang tenaga mekanik hanya 37 orang yang diberikan insentif sebesar Rp 33.300.000,00 dan terdapat 27 tenaga mekanik yang tidak mampu mencapai standar kerja yang ditetapkan.

Dilihat dari nilai koefisien regresinya diketahui bahwa pengaruh insentif terhadap kinerja karyawan sebesar 0,033. Artinya, jika perusahaan menambah insentif sebesar Rp $900.000,00$, maka kinerja karyawan yang diukur dari jumlah kendaraan yang diservice akan meningkat sebanyak 28 unit (0,033 x Rp 900.000,00/triwulan). Dengan demikian, dapat dikatakan bahwa terdapat pengaruh positif pemberian insentif terhadap kinerja karyawan.

Dilihat dari uji $\mathrm{z}$, diperoleh nilai $\mathrm{z}$ hitung sebesar 7,574 dengan tingkat signifikansi sebesar $0,000<$ tingkat signifikan $(\alpha)=0,05$, sehingga $\mathrm{H}_{0}$ ditolak dan $\mathrm{H}_{1}$ diterima. Artinya, pemberian insentif berpengaruh signifikan terhadap kinerja karyawan pada PT. Istana Deli Kencana Medan.

\section{KESIMPULAN DAN SARAN}

Berdasarkan analisis data dan setelah membahas hasil penelitian maka penulis mengambil kesimpulan sebagai berikut:

1. Persamaan regresi linear sederhana adalah $Y=515,462+0,033 X$. Artinya, pemberian insentif berpengaruh positif terhadap kinerja karyawan pada PT. Istana Deli Kencana Medan. Hal ini dapat dilihat dari nilai koefisien regresinya yang bertanda positif.

2. Nilai koefisien korelasi (R) sebesar 0,693, artinya pemberian insentif mempunyai hubungan yang cukup kuat dan positif terhadap kinerja karyawan pada PT. Istana Deli Kencana Medan. Nilai koefisien determinan $\left(\mathrm{R}^{2}\right)$ sebesar 0,481. Artinya, kinerja karyawan dapat dijelaskan oleh pemberian insentif sebesar $48,1 \%$ sedangkan $51,9 \%$ lagi dijelaskan oleh faktor lain.

3. Dilihat dari uji $\mathrm{z}$, diperoleh nilai $\mathrm{z}$ hitung sebesar 7,574 dengan tingkat signifikansi sebesar $0,000<$ tingkat signifikan $(\alpha)=0,05$, sehingga $\mathrm{H}_{0}$ ditolak dan $\mathrm{H}_{1}$ diterima. Artinya, pemberian insentif berpengaruh signifikan terhadap kinerja karyawan pada PT. Istana Deli Kencana Medan.

4. Kinerja karyawan PT. Istana Deli Kencana Medan belum optimal, hal ini terlihat dari besarnya persentase jumlah tenaga mekanik yang tidak mampu mencapai standar kinerja yang ditetapkan, karena besar insentif yang diberikan perusahaan belum sesuai yang diharapkan oleh karyawan.

\section{DAFTAR PUSTAKA}

Handoko, T. Hani, 2002. Manajemen Personalia dan Sumber Daya Manusia. Edisi Kedua, Cetakan Kelimabelas, Yogyakarta: BPFE-UGM. 
Hariandja, Mariot T.E., 2002. Manajemen Sumber Daya Manusia, Edisi Pertama, Jakarta: Grasindo.

Hasibuan, Malayu, 2003. Manajemen Sumber Daya Manusia, Cetakan Keenam, Jakarta: Bumi Aksara

Mathis, Robert L., dan John H. Jackson, 2002. Manajemen Sumber Daya Manusia, Alih Bahasa: Jimmy Sadeli dan Bayu Prawira Hie, Edisi Pertama, Jakarta: Salemba Empat.

Mubarak, Mawardi, 2014. Pengaruh Pemberian Insentif Terhadap Kinerja Karyawan Pada PT Kima Makasar. Jurnal: Universitas Hasanudin.

Nitisemito, Alex S. 2002. Manajemen Personalia. Edisi Kelima, Cetakan Kedua, Yogyakarta: BPFE.

Siagian, Sondang P., 2002. Manajemen Sumber Daya Manusia, Cetakan Kesembilan, Jakarta: Bumi Aksara.

Suharyanto, 2015. Pengaruh Pemberian Insentif Terhadap Kinerja Karyawan Pada Unit Kerja Produksi di PT Percatakan Rambang Palembang, Skripsi

Suhendra, 2015. Pengaruh Pemberian Insentif Terhadap Kinerja Karyawan Pada PT. Telkom Pakanbaru, Tesis: Fakultas Ekonomi Universitas Islam Negeri Sultan Syarif Kasim Riau. 